\title{
PANDEMI COVID-19 SEBAGAI BENTUK OVERMACHT TERHADAP PELAKSANAAN PERJANJIAN KREDIT DI PERBANKAN
}

\author{
Sherlin ${ }^{1}$, Lu Sudirman ${ }^{2}$ \\ ${ }^{1}$ Fakultas Hukum, Ilmu Hukum, Universitas Internasional Batam, 1851087.sherlin@,uib.edu \\ ${ }_{2}^{2}$ Fakultas Hukum, Ilmu Hukum, Universitas Internasional Batam
}

\section{ABSTRACT}

At the end of 2019, the world's first discovery of a highly contagious and rapidly growing virus called the Covid-19 virus. In legal terms, it is known as overmacht which means a forced state. The Covid-19 virus pandemic has grown rapidly since the beginning of 2019 until now. The biggest impact of the Covid-19 virus pandemic is the world economy. When it comes to the economy, the most influential field is banking. In the banking world, which provides loan services to customers, of course, it has had a big impact since the Covid-19 virus pandemic. Therefore, this paper aims to discuss the legal consequences of the overmacht condition in the banking sector, especially on the implementation of credit agreements in banking. The method used in this paper is normative law using a statutory approach, namely POJK and the Civil Code which contains the topic of discussion with secondary data types. With the overmacht condition, OJK as the authorized party issued a new POJK regulation regarding the implementation of credit in banking during this pandemic. Where overall the contents and provisions of the POJK are in accordance with applicable law, by emphasizing on the banking sector to continue to apply the precautionary principle in providing relaxation as an effort to relieve loans or debtor customer credit so that credit activities in banking remain organized and run well.

\section{ARTICLE INFO}

\section{Keywords:}

Agreement; Covid-19, Loan;

Pandemic;

Restructurisation

\section{Cite this paper:}

Sherlin, L. S. (2021).

Pandemi Covid-19 Sebagai

Bentuk Overmacht

Terhadap Pelaksanaan

Perjanjian Kredit Di

Perbankan. Widya

Yuridika: Jurnal Hukum, $4(2)$.

\section{Scope Article}

Administrative Law

\section{PENDAHULUAN}

Sebuah virus yang berkembang pesat pertama kali ditemukan di Kota Wuhan, Hubei, China pada akhir tahun 2019 disebut dengan Corona Virus Disease-19 (Covid-19). Penyebaran virus Covid-19 ini sangat cepat dari satu negara ke negara lainnya. ${ }^{1}$ Indonesia termasuk salah satu negara yang tergolong lambat dalam menangani virus Covid-19 ini. ${ }^{2} \mathrm{Di}$ Indonesia sendiri, pertama kali dinyatakan terdapat virus Covid-19 ialah pada bulan Maret tahun 2020 yaitu pada Warga Negara Indonesia di Kota Depok, Jawa Barat. Dikarenakan awal diberitakan nya kasus pertama di Indonesia, masih banyak orang beraktivitas di luar rumah tanpa memahami apa sebenarnya yang disebut dengan virus Covid-19 serta tindakan dari pemerintah yang cenderung lambat dalam menangani penyebaran virus Covid-19,

\footnotetext{
${ }^{1}$ Fransisco, W. (2020). Interaktif Masyarakat Terhadap Hukum Dalam Kehidupan Normal Baru Pasca COVID19. Journal of Judicial Review, 22(2), 151-164., hlm. 152.

2 Disemadi, H. S., \& Shaleh, A. I. (2020). Banking credit restructuring policy amid COVID-19 pandemic in Indonesia. Jurnal Inovasi Ekonomi, 5(02)., hlm. 63.
} 
kasus positif di Indonesia berkembang pesat sehingga banyak wilayah seperti kota besar di Indonesia menjadi zona merah. ${ }^{3}$

Pada awalnya pemerintah hanya memberikan himbauan untuk menjaga jarak dan tidak dianjurkan untuk beraktivitas di luar rumah agar dapat mencegah penyebaran virus Covid-19 di Indonesia. ${ }^{4}$ Dengan kondisi yang memaksa masyarakat untuk tidak dapat beraktivitas di luar rumah, mengakibatkan banyak perusahaan hingga restoran harus tutup. Banyak perusahaan yang memberhentikan kegiatan operasionalnya bahkan sampai dengan adanya pemutusan hubungan kerja (PHK) terhadap pekerjanya. ${ }^{5}$ Restoran atau tempat makan juga banyak yang tutup untuk mencegah penyebaran virus Covid-19. Ditambah lagi saat pertama kali ditetapkan peraturan terkait pembatasan sosial berskala besar (PSBB) di kota tertentu, yang semakin menghambat kegiatan masyarakat. ${ }^{6}$

Dengan kondisi akibat Covid-19 tersebut, banyak pekerja yang mengalami pemotongan gaji hingga PHK, perusahaan-perusahaan juga tidak dapat beroperasional seperti biasa, bahkan banyak perusahaan yang tidak dapat bertahan sehingga memberhentikan kegiatan operasional sementara hingga permanen. Alasan-alasan tersebut yang mendorong kelemahan ekonomi di masa pandemi Covid-19 ini. ${ }^{7}$ Kondisi ekonomi yang semakin melemah, berdampak besar untuk masyarakat seperti kekurangan dana untuk kebutuhan hidup. Kebutuhan manusia yang tergolong banyak pada umumnya seperti kebutuhan primer, sekunder, dan tersier, tidak dapat terpenuhi apabila kondisi ekonomi hancur. Salah satu contoh dari pengaruh lemahnya ekonomi pada masyarakat ialah tidak dapat memenuhi kewajiban pembayaran angsuran pinjaman di bank.

Perorangan atau badan usaha yang memanfaatkan jasa perbankan disebut dengan nasabah. ${ }^{8}$ Setiap nasabah dapat menggunakan jasa-jasa yang ditawarkan oleh bank sesuai dengan kebutuhan masing-masing nasabah. Mulai dari tabungan, deposito, hingga pinjaman atau kredit. Maka dari kebutuhan masing-masing nasabah tersebut, nasabah di perbankan pada umumnya terbagi menjadi nasabah simpanan (penyimpan dana) dan nasabah debitur (peminjam dana). Nasabah debitur yang menggunakan jasa bank dalam bentuk kredit, pada awalnya telah melewati proses pemenuhan beberapa syarat, mulai dari pengajuan permohonan oleh calon debitur, pengumpulan dan perlengkapan data calon debitur, pengecekan BI checking, survey agunan, kemudian marketing bank menyusun proposal pengajuan kredit, setelah pihak legal bank memeriksa dan direksi memutuskan setuju atas permohonan pengajuan kredit tersebut, maka akan diadakan pengikatan kredit antara pihak bank dengan nasabah debitur. ${ }^{9}$

Pada tahap pengikatan kredit, pihak bank akan mempersiapkan Surat Perjanjian Kredit yang berisi klausul-klausul terkait kredit dan ketentuan lainnya. Nasabah debitur akan diminta untuk menanda tangani apabila sepakat dengan isi Surat Perjanjian Kredit tersebut sebelum akhirnya kredit tersebut dicairkan. Setelah nasabah debitur menanda tangani Surat Perjanjian Kredit tersebut, berarti nasabah debitur sepakat dan akan bertanggung jawab terhadap isi dari Surat Perjanjian Kredit tersebut dan menanggung akibat hukum dari pelanggarannya sesuai dengan isi dari Surat Perjanjian Kredit tersebut.

\footnotetext{
3 Appludnopsanji, A., \& Disemadi, H. S. (2020). Problematika Kebijakan Pembebasan Narapidana sebagai Upaya Penanggulangan COVID-19 di Indonesia. Jurnal Wawasan Yuridika, 4(2), 131-148., hlm. 133.

${ }^{4}$ Disemadi, H. S., \& Handika, D. O. (2020). Community compliance with the covid-19 protocol hygiene policy in Klaten Regency, Indonesia. Legality: Jurnal Ilmiah Hukum, 28(2), 121-133., hlm. 126.

${ }^{5}$ Taniady, V., Riwayanti, N. W., Anggraeni, R. P., Ananda, A. A. S., \& Disemadi, H. S. (2020). PHK Dan Pandemi Covid19: Suatu Tinjauan Hukum Berdasarkan Undang-Undang Tentang Ketenagakerjaan Di Indonesia. Jurnal Yustisiabel, 4(2), 97-117., hlm. 100.

${ }^{6}$ Kang, C., \& Disemadi, H. S. (2021, March). The COVID-19 Pandemic Outbreak Impact And Prevention From Legal Perspective: An Indonesian Experience. In CoMBInES-Conference on Management, Business, Innovation, Education and Social Sciences Vol. 1, No. 1, 134-144., hlm. 138.

7 Syaifudin, A., \& Ernawati, E. (2020). Indonesia Investment Rules: Kajian Hukum Pemulihan Dan Pengembangan Ekonomi Nasional Dimasa COVID-19. Journal of Judicial Review, 22(2), 195-214., hlm. 197.

${ }^{8}$ Pasal 1 Ayat 16 UU No. 10 Tahun 1998 tentang Perbankan

${ }^{9}$ Charlina. (2020). 10 Alur Kredit Di Bank. Diambil 2 Juni 2021. Dari https://wartadana.com/10-alur-kredit-di-bank/
} 
Dari Surat Perjanjian Kredit tersebut timbul hubungan hukum antara bank dan nasabah debitur. Setiap hubungan hukum yang timbul mengandung hak dan kewajiban yang wajib dilaksanakan oleh para pihak. ${ }^{10}$

Nasabah debitur yang telah sepakat menanda tangani Surat Perjanjian Kredit tersebut wajib melaksanakan kewajiban nya sebagai debitur atau peminjam dana. Apabila pada suatu saat terdapat kondisi dimana nasabah debitur tidak dapat melaksanakan ataupun hanya melaksanakan sebagian kewajiban yang ia miliki sebagai peminjam dana tidak dapat terpenuhi, maka nasabah debitur dapat dinyatakan wanprestasi. Wanprestasi adalah pemenuhan kewajiban yang tidak terpenuhi atau lebih dikenal dengan peringkaran janji, atau terdapat tindakan lalai yang dilakukan oleh debitur baik karena tidak melaksanakan kewajiban ataupun melakukan perbuatan yang dilarang dalam perjanjian. ${ }^{11}$ Pada saat sebelum adanya pandemi Covid-19 ini, kredit bermasalah atau kurang lancar sudah sering terjadi dalam perbankan, mulai dari tidak adanya itikad baik dari nasabah debitur hingga nasabah debitur mengalami kerugian besar dalam usahanya sehingga tidak dapat melakukan pembayaran kepada bank. Kredit bermasalah pada umumnya dinilai timbul karena adanya risiko pada saat pemberian kredit atau pinjaman tersebut. Dalam hal ini, kredit bermasalah erat kaitannya dengan risiko kredit, risiko kepatuhan, dan risiko hukum. Sebelum adanya pandemi Covid-19 pun, upaya penyelesaian kredit bermasalah telah diatur dalam hukum perbankan, yaitu dengan restrukturisasi kredit.

Terkait dengan pelaksanaan perjanjian kredit, bagaimana apabila terjadi hal diluar kemampuan nasabah debitur seperti pada masa pandemi Covid-19 yang menarik kebawah kondisi ekonomi setiap negara? Pada saat disepakatinya perjanjian kredit tersebut, tentunya belum dan bahkan tidak ada gambaran bahwa akan terjadi pandemi yang berdampak buruk bagi kondisi ekonomi dunia. Menurut KUH Perdata, terdapat suatu istilah bernama overmacht, dimana yang berarti terdapat suatu kondisi bahwa debitur terhambat untuk melaksanakan kewajiban atau melaksanakan perbuatan yang melanggar perjanjian. Berdasarkan pengertian tersebut disesuaikan dengan terminology yaitu keadaan terpaksa. Keadaan terpaksa atau dapat diartikan dengan keadaan diluar kendali suatu pihak yang mempengaruhi pelaksanaan kewajiban perjanjian atas kejadian tersebut.

Dengan adanya pandemi Covid-19 yang menimbulkan kondisi overmacht pada nasabah debitur di perbankan, Otoritas Jasa Keuangan (OJK) sebagai lembaga yang mengawasi kegiatan usaha dalam bidang perbankan menyadari bahwa penyebaran virus Covid-19 secara global memberikan dampak secara langsung maupun tidak terhadap kapasitas dan kinerja nasabah debitur dalam melaksanakan kewajiban atas kreditnya. Kondisi ekonomi masyarakat dunia terdampak oleh pandemi Covid-19 ini, nasabah debitur sebagai peminjam dana kepada bank menjadi kesulitan bahkan tidak dapat memenuhi kewajibannya untuk melakukan pembayaran angsuran kepada pihak bank. Apabila dibiarkan kondisi seperti ini terus berjalan, kondisi ekonomi nasional akan semakin memburuk dikarenakan kegiatan perbankan tidak berjalan baik. Maka perlu diadakannya tindakan untuk menetralkan kondisi yang disebabkan pandemi Covid-19 ini, dimana kondisi tersebut dalam istilah hukum disebut dengan overmacht. Oleh karena itu, 0JK mengeluarkan POJK No. 11/POJK.03/2020 tentang Stimulus Perekonomian Nasional Sebagai Kebijakan Countercyclical Dampak Penyebaran Coronavirus Disease 2019 dengan tujuan untuk membantu pengoptimalisasian kinerja bank terkhusus dalam fungsi intermediasi, memelihara kondisi stabil sistem keuangan, serta mendorong perkembangan ekonomi perlu ditentukan kebijakan stimulus ekonomi sebagai countercyclical dalam pandemi Covid-19 ini.

Kebijakan yang dikeluarkan oleh OJK tersebut juga menekankan untuk tetap menerapkan prinsip kehati-hatian oleh pihak bank. Segala bentuk putusan bank kepada penanganan kredit kurang lancar atas nasabah debitur di masa pandemi Covid-19 ini

\footnotetext{
${ }^{10}$ Hetharie, Yosia. (2019). Perjanjian Nominee Sebagai Sarana Penguasaan Hak Milik Atas Tanah Oleh Warga Negara Asing Menurut KUHPerdata. Jurnal SASI. doi: https://doi.org/10.47268/sasi.v25i1.147

11 Pengertian, Bentuk, Penyebab, dan Hukum Wanprestasi. http://www.dppferari.org/pengertian-bentukpenyebab-dan-hukum-wanprestasi/ (diakses pada tanggal 01 Juni 2021)
} 
diambil oleh pihak bank sendiri. Pihak bank dapat menilai apakah nasabah debiturnya memenuhi persyaratan dan kriteria untuk diberikan restrukturisasi dengan memperhatikan ketentuan yang dijelaskan dalam POJK tersebut. ${ }^{12}$

\section{METODE}

Dalam penyusunan tulisan ini, metode yang digunakan ialah hukum normatif dengan menggunakan pendekatan perundang-undangan (statute approach) yaitu POJK dan KUH Perdata yang berisi mengenai topik pembahasan dengan jenis data sekunder. Mengingat tulisan ini memuat pembahasan mengenai akibat hukum dari suatu kondisi overmacht dalam pandemi Covid-19 terhadap perjanjian kredit maka teknik pengumpulan data yang digunakan ialah teknik pengumpulan data sekunder, dengan melakukan penelitian dari bahan-bahan peraturan perundang-undangan dan hukum tertulis yang bersangkutan dengan hukum perbankan, hukum perdata yang spesifiknya mengatur tentang perjanjian kredit dan disangkut-pautkan dengan kondisi overmacht. Untuk memberikan analisis yang baik terhadap kondisi overmacht akibat dari pandemi Covid-19, metode analisis yang digunakan ialah metode analisis data kualitatif, dengan memanfaatkan data yang diperoleh dari dokumen atau jurnal terkait topik pembahasan tulisan ini.

\section{HASIL DAN PEMBAHASAN}

\section{Pandemi Covid-19 Di Indonesia}

Awal pertama kali diberitakan nya kasus pertama Warga Negara Indonesia positif terinfeksi Covid-19 ialah pada tanggal 2 Maret 2020 di Kota Depok, Jawa Barat. Sejak saat itu, penyebaran virus Covid-19 semakin cepat terutama di kota-kota besar seperti salah satu contohnya Jakarta. Jakarta merupakan kota besar yang memiliki persentase tinggi untuk pasien positif Covid-19. Indonesia dapat dikatakan sebagai salah satu negara yang penanganan terhadap penyebaran Covid-19 sangat lambat, ditambah lagi kurangnya kesadaran masyarakat. Dari awal ditemukan nya virus Covid-19 di Kota Wuhan, Hubei, China ini, memang belum didapatkan mengenai faktor yang memicu timbulnya virus ini, sehingga banyak masyarakat yang sampai saat ini belum percaya dan menganggap remeh wabah virus ini. ${ }^{13}$

Dampak dari adanya penyebaran Covid-19 sangat terasa terutama dalam perekonomial nasional. Pemerintah mengeluarkan regulasi terkait penanganan dan pencegahan penyebaran virus Covid-19, yaitu diberlakukan social distancing dan PSBB. Meskipun tujuan dikeluarkan dan diberlakukannya regulasi tersebut bermaksud baik, namun tetap berdampak bagi perusahaan hingga restoran. Dengan pembatasan yang ada, banyak perusahaan yang terhambat kegiatan operasional hingga berhenti secara permanen operasional nya, yang pada akhirnya pekerja pun menerima dampak dari tindakan tersebut, mulai dari pemotongan gaji hingga dilakukan PHK oleh pihak perusahaan.

Dengan kondisi tersebut, kondisi keuangan masyarakat semakin buruk. Meskipun dalam keadaan pandemi, kebutuhan masyarakat sebagai makhluk sosial tetap ada. Mulai dari kebutuhan primer, sekunder, dan tersier. Salah satu dampak dari melemahnya kondisi ekonomi nasional ialah kekurangan dana masyarakat untuk bertahan hidup serta melaksanakan kewajiban nya, yaitu pinjaman atau kredit di bank. Berjalan dari waktu ke waktu, kondisi pandemi Covid-19 ini membaik pada akhir tahun 2020. Pada pertengahan tahun 2021, kondisi semakin kurang stabil. Oleh karena itu, pemerintah menghimbau masyarakat untuk tetap menjaga jarak serta mengurangi aktivitas di luar rumah apabila tidak diperlukan. Masih ada perusahaan-perusahaan yang menerapkan sistem kerja work from home dalam rangka pencegahan penyebaran virus Covid-19 ini.

\footnotetext{
12 Sumaryanto, A Djoko \& Kunarso. (2020). Eksistensi Perjanjian Ditengah Pandemi Covid19. Jurnal Batulis Civil Law Review. doi: $\quad$ https://doi.org/10.47268/ballrev.v1i1.423

${ }^{13}$ Rezki \& Yunus, N. (2020). Kebijakan Pemberlakuan Lockdown Sebagai Antisipasi Penyebaran Corona Virus Covid19. Jurnal Sosial dan Budaya Syar-i. doi: https://doi.org/10.15408/sjsbs.v7i3.15083
} 
Awal tahun 2021, ditemukan vaksin khusus untuk pencegahan penyebaran virus Covid-19, yaitu yang diproduksi oleh China, serta beberapa jenis vaksin lain yang diproduksi oleh negara-negara Eropa. Dengan ditemui dan diproduksinya vaksin, diharapkan dunia akan semakin membaik kedepan nya terutama untuk ekonomi dunia.

\section{Penyelesaian Kredit Bermasalah Sebelum Covid-19}

Sebelum terjadinya penyebaran virus Covid-19, kredit bermasalah sudah sering terjadi dalam dunia perbankan. Banyak faktor-faktor yang mempengaruhi terjadinya kredit bermasalah. Pada umumnya, kredit bermasalah terjadi karena nasabah debitur tidak dapat memenuhi kewajiban atas pinjaman nya di bank. Dalam perbankan, kredit bermasalah timbul karena adanya risiko pada saat pemberian kredit tersebut. Terdapat beberapa macam risiko dalam perbankan, seperti risiko kredit, risiko pasar, risiko likuiditas, risiko operasional, risiko hukum, risiko reputasi, dan risiko strategik. Pada kredit bermasalah besar kaitannya dengan risiko kredit, risiko kepatuhan, dan risiko hukum. Wanprestasi dalam hukum perbankan berbeda dengan yang ada di hukum perdata. Wanprentasi dalam perbankan diatur dalam Pasal 31 PBI No. 14/15/PBI/2012, disebutkan syarat-syarat untuk menyatakan nasabah debitur wanprestasi yaitu tunggakan sudah sampai dengan 90 hari, tidak adanya pembayaran terhadap utang pokok dan/atau bunga dan/atau biaya lainnya pada saat aset produktif jatuh tempo, bisa juga wanprestasi muncul dari tidak dipenuhinya ketentuan lain selain pembayaran yang memicu wanprestasi.

Penilaian suatu kredit yang macet pun, tidak secara langsung status pinjaman atau kredit nasabah debitur langsung dinyatakan macet. Sebelum akhirnya suatu status pinjaman atau kredit dinyatakan macet, telah melewati beberapa tahapan seperti lancar, dalam perhatian khusus, kurang lancar, diragukan, hingga akhirnya dinyatakan macet. Faktor penyebab suatu kredit bermasalah dapat dipandang dari beberapa sudut, yaitu kelemahan dalam analisis kredit, kelemahan dalam dokumen kredit, kelemahan dalam supervise kredit, kecerobohan petugas bank, kelemahan dalam jaminan, hingga kecurangan petugas bank. Penyelesaian kredit bermasalah dapat dilakukan upaya penyelesaian kredit bermasalah seperti:

a) Restrukturisasi Kredit

Dalam restrukturisasi kredit, berarti adanya tawaran dari pihak bank atau bahkan adanya permohonan langsung dari nasabah debitur untuk menyusun atau mengatur ulang terkait kredit atau pinjaman nya agar adanya keringanan dalam pembayaran utang oleh nasabah debitur. Cara restrukturisasi kredit antara lain dengan perpanjangan jangka waktu pinjaman, pembayaran hanya utang bunga saja sampai dengan waktu yang ditentukan (grace period), dan ada juga penurunan suku bunga namun sangat jarang disarankan oleh pihak bank. Namun perlu diketahui, restrukturisasi kredit hanya dapat dilakukan kepada nasabah debitur dengan itikad baik. Hal ini sering sekali menjadi perdebatan, contohnya terdapat seorang nasabah debitur yang sudah mengalami kredit kurang lancar dan belum melakukan pembayaran atas utang atau pinjaman nya tersebut, tiba-tiba datang dan mengajukan restrukturisasi atas pinjaman atau kreditnya, dalam kasus seperti ini, pihak bank sangat jarang bahkan bisa menolak pengajuan yang dimohon oleh nasabah debitur kredit bermasalah tersebut. Setelah dilaksanakan nya restrukturisasi kredit, akan diikuti dengan addendum perjanjian kredit atau perubahan perjanjian kredit yang dapat dilaksanakan melalui proses bawah tangan maupun dengan notaris.

b) Agunan Yang Diambil Ahli

Agunan Yang Diambil Ahli (AYDA) diatur dalam PBI No. 14/15/PBI/2012. AYDA merupakan aset atau jaminan yang kepemilikan nya diambil ahli oleh pihak bank, dimana sebelum adanya AYDA, bank hanya sebagai pemegang hak tanggungan, namun dengan adanya AYDA ini, bank menjadi pemilik atas aset atau jaminan tersebut. Cara memperoleh dapat melalui perlelangan, sukarela, dan melalui Kuasa Untuk Menjual yang dilakukan diluar proses perlelangan. Dimana jaminan tersebut harus memiliki dokumen yang sah sesuai dengan peraturan perundang-undangan, memberikan hak 
preference kepada bank (hak yang didahulukan), dan dilindungi oleh asuransi. AYDA juga diatur dalam Pasal 12 UU Perbankan, yaitu jaminan dapat diambil ahli dengan syarat kredit telah macet 90 hari dan paling lambat sejak satu tahun diambil ahli oleh bank, jaminan tersebut harus segera dicairkan atau dijual agar dapat menutupi kredit yang bermasalah tersebut. AYDA juga terdapat kategorinya sendiri yaitu:

- Lancar (0 sampai dengan 1 tahun)

- Kurang Lancar (1 sampai dengan 3 tahun)

- Diragukan (3 sampai dengan 5 tahun)

- Macet (diatas 5 tahun) ${ }^{14}$

c) Eksekusi Objek Jaminan Kebendaan

Di Indonesia lembaga jaminan yang diakui antara lain ialah Gadai (Pasal 1155 KUH Perdata), Hipotek (Pasal 1178 KUH Perdata), Hak Tanggungan (Pasal 20 UU No. 4 Tahun 1996), Fidusia (Pasal 29 UU No. 42 Tahun 1999).

\section{Akibat Hukum dari Overmacht Covid-19 di Perbankan}

Setiap nasabah yang menggunakan jasa pinjaman yang diberikan oleh bank disebut dengan nasabah debitur. ${ }^{15}$ Pihak bank dan nasabah debitur memiliki hubungan hukum yang timbul dari perjanjian kredit. Nasabah debitur yang telah sepakat dengan klausul-klausul atau ketentuan yang tertera di dalam Surat Perjanjian Kredit pada saat pengikatan kredit wajib melaksanakan dan memenuhi kewajiban nya sesuai dengan isi dari Surat Perjanjian Kredit tersebut dan menanggung akibat hukum yang mungkin akan timbul. Salah satunya yaitu, melaksanakan pembayaran nya setiap bulan sesuai dengan nilai angsuran yang ditetapkan oleh bank dari awal hingga lunasnya kredit tersebut.

Namun, tanpa diduga dan diketahui, tahun 2020 menjadi tahun yang sulit bagi semua sektor perusahaan terutama perbankan. Dikarenakan oleh banyak faktor seperti PHK, tutupnya usaha nasabah debitur, menghambat para nasabah debitur untuk memenuhi dan melaksanakan kewajiban atas kreditnya. Apabila terus dibiarkan dan tidak secepatnya ditangani, maka kondisi ekonomi di sektor perbankan akan berantakan dan ditakutkan terulang kembali krisis moneter seperti pada tahun 1998. Mengingat perjanjian kredit yang dilaksanakan sebelum masa pandemi Covid-19 tentunya sangat berbeda dengan keadaan saat ini, sehingga adanya gap untuk memenuhi ketentuan perjanjian kredit.

Dengan kondisi yang timbul dan diluar kendali suatu pihak, disebut sebagai overmacht, dimana dalam KUH Perdata disebutkan bahwa overmacht merupakan suatu kondisi seorang debitur tidak dapat melaksanakan prestasi atau kewajibannya kepada kreditur setelah disekapati perjanjiannya, yang dikarenakan debitur tidak dapat dinyatakan bersalah dan menanggung risiko karena adanya keadaan diluar kuasa debitur.

"Pasal 1244 KUH Perdata menekankan, jika ada alasan untuk itu si berhutang harus dihukum mengganti biaya, rugi dan bunga, bila ia tidak membuktikan, bahwa hal tidak dilaksanakan atau tidak pada waktu yang tepat dilaksanakannya perjanjian itu, disebabkan karena suatu hal yang tak terduga, pun tak dapat dipertanggungjawabkan padanya, kesemuanya itu pun jika itikad buruk tidak ada pada pihaknya."

Dari penjelasan pasal tersebut, kemudian dilanjutkan lagi,

"Pasal 1245 KUH Perdata menekankan, Tidaklah biaya, rugi dan bunga harus digantinya, apabila karena keadaan memaksa (overmacht) atau karena suatu keadaan yang tidak disengaja, si berutang berhalangan memberikan atau berbuat sesuatu yang diwajibkan, atau karena hal-hal yang sama telah melakukan perbuatan yang terlarang."

\footnotetext{
${ }^{14}$ Peraturan Bank Indonesia No. 14/15/PBI/2012

${ }^{15}$ Pasal 1 Ayat 18 UU No. 10 Tahun 1998 Tentang Perbankan.
} 
Sifat overmacht pada umumnya terbagi menjadi dua yaitu, overmacht tetap dan overmacht sementara. Perbedaan nya ialah dalam overmacht tetap, debitur dinyatakan tidak dapat memenuhi prestasi atau kewajiban nya lagi sepenuhnya karena overmacht, sedangkan overmacht sementara, debitur dinilai dapat berprestasi dan melaksanakan kewajiban nya kembali setelah setelah atau berakhirnya keadaan overmacht, apabila ditinjau dari UU No. 24 Tahun 2007 tentang Penanggulangan Bencana, Covid-19 dapat disebut sebagai bencana non-alam dalam bentuk pandemi. ${ }^{16}$ Namun, sesuai dengan ketentuan yang dikeluarkan OJK, nasabah debitur yang terdampak Covid-19 dapat mengajukan restrukturisasi sesuai ketentuan POJK No. 11/POJK.03/2020.

Akibat hukum dari overmacht pandemi Covid-19 di sektor perbankan ialah nasabah debitur tidak dituntut membayar ganti atas kerugian, beban risiko tetap sama terutama pada keadaan overmacht sementara, serta kreditur dalam konteks ini ialah bank, tidak memiliki hak untuk pemenuhan pelaksanaan kewajiban atau prestasi, namun demi hukum terbebaskan dari kewajibannya untuk serahkan kontras prestasi atau kewajiban. ${ }^{17}$

\section{Kebijakan Penanggulangan Perjanjian Kredit Akibat Overmacht Covid-19}

Selain melakukan penanggulangan terhadap penyebaran virus Covid-19, pemerintah jugua melakukan penanggulangan dibidang ekonomi, salah satunya dalam bidang perbankan. Dalam bidang perbankan, lembaga yang berwenang sebagai pengawas ialah OJK. OJK memandang bahwa kondisi ekonomi yang memburuk sejak adanya pandemi Covid-19 ini berdampak besar bagi sektor perbankan. Akibat dari kesulitan bagi nasabah debitur untuk melaksanakan dan memenuhi kewajibannya di bank, banyak nasabah debitur mengeluh terkait sulitnya pemberian keringanan terkait pinjaman atau kredit nasabah debitur.

Oleh karena itu, OJK mengeluarkan peraturannya dengan nomor POJK No. 11/P0JK.03/2020 tentang Stimulus Perekonomian Nasional Sebagai Kebijakan Countercyclical Dampak Penyebaran Coronavirus Disease 2019 dengan tujuan untuk membantu pengoptimalisasian kinerja bank terkhusus dalam fungsi intermediasi, memelihara kondisi stabil sistem keuangan, serta mendorong perkembangan ekonomi perlu ditentukan kebijakan stimulus ekonomi sebagai countercyclical dalam pandemi Covid-19 ini. Pada POJK tersebut sebenarnya tidak hanya fokus pada perbankan namun juga leasing (pembiayaan). Dasar dikeluarkan POJK ini dapat dipandang dari tiga sisi, antara lain:

a. Filosofis

Untuk melihat dari sisi filosofis mengapa dikeluarkan nya POJK terkait stimulus perokonomian ini dapat dipandang melalui Pancasila, dimana Pancasila merupakan landasan hukum nasional, yang mengandung nilai yang berkaitan dengan semua aspek kehidupan bermasyarakat. Sila terakhir Pancasila menyinggung tentang keadilan sosial. Dimana nilai sosial harus diwujudkan bersama demi kehidupan bersama yang sejahtera. Mewujudkan tujuan untuk sejahtera masyarakat dapat dilihat dari beberapa aspek, yaitu sosial, ekonomi, dan kesehatan. Ekonomi termasuk salah satu faktor terwujudnya kesejahteraan rakyat, maka dengan dikeluarkan POJK terbaru ini diharapkan dapat membantu memulihkan perekonomian nasional.

b. Yuridis

Alasan yuridis menggambarkan bahwa suatu aturan yang dibentuk untuk mengisi kekosongan hukum atau mengatasi permsalahan hukum dengan mempertimbangkan aturan yang telah ada, yang akan dicabut atau yang akan diubah guna menjamin kepastian hukum dan rasa keadilan masyarakat.18 Dalam UU Perbankan disebutkan bahwa sektor perbankan di Indonesia memiliki tujuan untuk membantu pembangunan nasional dalam perkembangan serta pertumbuhan ekonomi, apabila dilihat POJK yang

\footnotetext{
${ }^{16}$ Pasal 1Ayat (3) UU No.24 Tahun 2007 tentang Penanggulangan Bencana.

${ }^{17}$ Tjoanda, Merry \& Yosia Hetharie. (2021). Covid-19 Sebagai Bentuk Overmacht Dan Akibat Hukumnya. Jurnal SASI. doi: https://doi.org/10.47268/sasi.v27i1.447

18 UU No. 12 Tahun 2011 tentang Pembentukan Peraturan Perundang-Undangan.
} 
dikeluarkan, maka dapat disimpulkan bahwa POJK tersebut dibentuk karena merupakan upaya dari pemerintah dalam menanggulangi masalah ekonomi nasional dimasa pandemi Covid-19 ini.

c. Sosiologis

Alasan sosiologis dikeluarkannya POJK tersebut ialah dapat memberikan pengaruh kepada debitur untuk memenuhi kewajiban pembayaran kredit atau pembiayaan, akibat terpengaruhnya debitur dalam memenuhi kewajiban pembayaran kredit yang berpengaruh terhadap pertumbuhan ekonomi dikarenakan terganggunya kinerja perbankan, kebijakan tersebut dampak penyebaran Covid-19 merupakan kebijakan stimulus terhadap perenomian akibat pandemi COVID-19 yang diharapkan dapat mengoptimalisasi kinerja perbankan dengan tetap memperhatikan prinsip kehatihatian.

Dalam POJK tersebut disebutkan penyelamatan kredit dimasa pandemi Covid-19 yaitu dengan cara restrukturisasi. Para nasabah debitur dapat mengajukan keringanan atau relaksasi dengan enam cara yaitu ${ }^{19}$ :
a) Penurunan suku bunga
b) Perpanjangan jangka waktu
c) Pengurangan tunggakan pokok
d) Pengurangan tunggakan bunga
e) Penambahan fasilitas kredit
f) Konversi kredit

\section{5. $\quad$ Risiko Yang Timbul dari Perjanjian Kredit}

Perjanjian kredit pada umumnya diikuti dengan perjanjian jaminan atau accessoir yang mana berhentinya jaminan bergantung pada perjanjian pokoknya. Risiko-risiko yang berkemungkinan terjadi dalam perjanjian kredit bank, antara lain:

a. Risiko kredit yang paling umum terjadi dan merupakan inti dari semua risiko pasar komoditas biasanya terjadi akibat wanprestasi atau nasabah debitur kehilangan tanggung jawab. Maka dari itu, banyak nasabah debitur yang tidak ingin atau tidak mampu memenuhi kepentingan dan kewajibannya untuk membayar jumlah bunga dan utang pokok.

b. Manajemen risiko mencakup segala aspek bisnis, berkemungkinan terjadi karena tak mampu bersaing atau sudah terlambat untuk bersaing.

c. Risiko pengendalian yang dikaitkan dengan peraturan yang berbeda atau aturan sebagai pedoman perbankan.

d. Risiko operasional sangat berkaitan dengan sistem sehingga jika sistem kurang tepat dan tidak sesuai akan menyebabkan kerugian atau mengurangi nilai layanan kepada pelanggan,

e. Risiko produk yang berhubungan dengan harga barang, harga barang memiliki pengaruh besar terhadap perbankan dan lembaga keuangan lainnya.

f. Risiko sumber daya manusia akibat kesalahan yang disebabkan oleh gerakan manusia.

g. Risiko hukum yang timbul dari sistem hukum yang dapat menghilangkan atau mengalami penurunan nilai para pemegang saham karena adanya tuntutan hukum kepada bank oleh debitur.

Dalam menyalurkan kredit, pihak bank harus bertindak dengan penuh kehati-hatian dalam mengambil resiko serta langkah selanjutnya, karena resiko terbesar dibebani oleh bank yang berasal dari kegiatan pemberian kredit. Gagalnya pemenuhan kewajiban baik hutang pokok maupun bunga terjadi apabila debitur gagal melaksanakan dan memenuhi kewajibannya. Dana bank yang tidak kembali mengakibatkan bank tidak dapat memenuhi

\footnotetext{
${ }^{19}$ POJK No. 11/POJK.03/2020 tentang Stimulus Perekonomian Nasional.
} 
kewajibannya kepada pihak ketiga lainnya, menyebabkan dana yang seharusnya dipakai menjadi terhambat dan hal ini disebut sebagai risiko likuiditas. ${ }^{20}$

\section{Restrukturisasi Sebelum Masa Pandemi Covid-19 \& Pemberlakuan POJK No. 11/P0JK.03/2020 di Masa Pandemi Covid-19}

Sebelum adanya masa pandemi Covid-19, nasabah debitur dapat mengajukan permohonan untuk restrukturisasi kredit apabila nasabah debitur mengalami kesulitan untuk melaksanakan kewajiban pembayarannya kepada bank. Namun, harus disertai dengan syarat nasabah debitur memiliki prospek usaha ataupun kemungkinan peningkatan kondisi keuangannya setelah dilakukannya restrukturisasi kredit ini. Sebelum masa pandemi Covid-19, tentunya jumlah nasabah yang mengajukan permohonan restrukturisasi lebih sedikit dan alasan setiap nasabah cenderung berbeda. Contohnya, saat pemberlakuan pajak atas pengiriman barang impor atau ekspor, untuk nasabah yang usahanya bergerak dalam bidang tersebut tentunya terdampak atas ketentuan baru tersebut, sehingga dengan adanya kondisi tersebut, usahanya terganggu dan mengalami penurunan pendapatan, pada akhirnya nasabah mengalami kesulitan dalam membayar angsurannya kepada pihak bank. Maka, nasabah dapat mengajukan permohonan restrukturisasi kreditnya, dengan syarat record pembayarannya lancar sebelum diberlakukannya ketentuan pajak tersebut serta melampirkan planner terhadap usahanya untuk kedepannya, atau alternatif lain yang memungkinkan nasabah dapat memenuhi kewajibannya terhadap bank.

Akibat dari penurunan kondisi ekonomi nasional yang berdampak pada dunia perbankan, Otoritas Jasa Keuangan yang berperan sebagai lembaga pengawas dalam Perbankan mengeluarkan peraturan baru sebagai kebijakan countercyclical dari dampak penyebaran Covid-19. Pada pertengahan masa pandemi Covid-19, Presiden Joko Widodo menyebutkan kepada public terkait akan diberikan keringanan terhadap nasabah dari perusahaan leasing maupun perbankan. Namun hingga beberapa saat sebelum dikeluarkan POJK tersebut, memicu kekacauan antara masyarakat dan perusahaan leasing dan perbankan. Masyarakat menuntut bahwa akan diberikan keringanan dan beberapa menyebutkan akan adanya penghapusan utang (tanpa perlu melakukan pembayaran). Oleh karena itu, dibentuk lah POJK ini untuk menjawab permasalahan yang dipernyatan masyarakat selaku debitur.

Namun, setelah diterbitkannya POJK ini, masih banyak nasabah debitur yang kurang memahami terkait isi dari peraturan tersebut. Ketentuan-ketentuan yang tercantum di dalam POJK tersebut pada dasarnya tidak berbeda jauh dengan penyelesaian kredit bermasalah sebelum adanya pandemi Covid-19 dalam UU Perbankan. Tujuan dibentunya POJK ini adalah memelihara dan membangkitkan kembali kinerja perbankan dan tingkat stabil suatu sistem keuangan sehingga meningkatkan kondisi ekonomi nasional. Dampak dari penyebaran Covid-19 ini menghambat nasabah debitur dalam memenuhi kewajiban atas pembayaran utang, dikarenakan pada masa pandemic Covid-19 ini banyak perusahaan besar hingga UMKM pun berdampak dalam operasional dan kegiatan usahanya. Sehingga bagi karyawan atau pekerja terjadinya pemutusan hubungan kerja, pemotongan gaji, hingga penutupan atau pemberhentian kegiatan usaha.

Dalam kasus pandemi Covid-19 ini, nasabah debitur tidak dapat memenuhi kewajiban nya dikarenakan adanya kondisi overmacht atau kondisi terpaksa atau kondisi yang muncul diluar kendali nasabah debitur. Apakah nasabah debitur yang tidak memenuhi kewajiban nya dalam kondisi overmacht dapat disebut melakukan wanprestasi? Bagaimana upaya penyelesaian kredit bermasalah terhadap kredit nasabah debitur yang tunggak sejak masa pandemi Covid-19? Otoritas Jasa Keuangan mengeluarkan kebijakan yang dapat mendukung stimulus pertumbuhan yaitu, dengan cara:

"Kebijakan yang mendukung stimulus pertumbuhan ekonomi sebagaimana dimaksud pada ayat (1) meliputi:

a. kebijakan penetapan kualitas aset; dan

20 Yusmita. (2019). Perlindungan Hukum Terhadap Debitur dan Kreditur Dalam Melakukan Perjanjian Baku. Surabaya: DIH Jurnal Ilmu Hukum. 


\section{b. kebijakan restrukturisasi kredit atau pembiayaan."21}

Setelah bank memberikan fasilitas keringanan kepada nasabah debitur berdasarkan ketentuan POJK tersebut, harus menyampaikan laporan dengan format yang tercantum pada lampiran POJK tersebut. Salah satu hal yang penting untuk diketahui oleh nasabah debitur, bahwa setiap bank memiliki ketentuan khusus masing-masing yang pada dasarnya sama yaitu, nasabah debitur yang dapat melaksanakan relaksasi atas kreditnya adalah nasabah yang sebelum adanya pandemi Covid-19 memang pembayaran atas utangnya lancar dan tidak ada tunggakan, nasabah debitur yang dipertimbangkan untuk diberikan relaksasi adalah nasabah debitur yang pada dasarnya beritikad baik. Ketentuan tersebut diberlakukan oleh pihak bank karena masih banyak nasabah debitur yang sebelum masa pandemi Covid19 terkait atas pembayaran utangnya sudah tidak lancar dan bahkan tidak melakukan pembayaran sama sekali atas utang yang tertunggak tersebut, datang memohon pengajuan untuk relaksasi kredit dengan alasan Otoritas Jasa Keuangan mengeluarkan peraturan bahwa setiap nasabah debitur dapat memohon pengajuan relaksasi atau keringanan untuk kredit nya. Kemudian, dikarenakan pandemi virus ini bersifat sementara dan tidak ada yang tahu kapan akan selesainya pandemi ini, tentunya kondisi ini tidak dapat dikatakan kondisi permanen, sehingga pada Pasal 10 POJK tersebut menyebutkan penerapan kebijakan untuk nasabah debitur tersebut berlaku sampai tanggal 31 Maret 2021.22

Salah satu contoh relaksasi yang diberikan bank kepada nasabah debitur ialah Grace Period, dimana nasabah debitur hanya perlu membayar angsuran bunga tanpa angsuran pokok dengan jangka waktu yang telah ditentukan, sehingga mendapatkan keringanan untuk pembayaran namun perlu diketahui Grace Period ini tidak mengurangi jumlah dari utang pokok. Sehingga, pada saat periode Grace Period selesai, nasabah debitur tetap wajib membayar angsuran pokok beserta angsuran bunga yang tersisa seperti normalnya.

\section{PENUTUP}

Sebelum adanya pandemi Covid-19 ini, tidak sedikit nasabah debitur yang memiliki kredit bermasalah di bank. Sehingga, sebelum dikeluarkan POJK No. 11/POJK.03/2020 pun sebenarnya pada dasarnya sudah ada UU Perbankan dan PBI yang mengatur terkait penyelesaian kredit bermasalah di perbankan. Dengan memandang dari sudut risiko, keterkaitan kredit bermasalah dan risiko sangat erat. Sebelum adanya masa pandemi Covid19, nasabah debitur tidak dapat memenuhi kewajiban nya bisa dinyatakan wanprestasi dengan ketentuan yang dijelaskan dalam PBI. Namun, dengan pandemi Covid-19 yang timbul tanpa sepengetahuan dan diluar kendali masyarakat, pandemi Covid-19 ini, dapat dianggap sebagai kondisi overmacht atau kondisi terpaksa. Dimana terdapat suatu kondisi diluar kendali nasabah debitur sehingga menghambat kewajiban pembayaran atas utang nasabah debitur tersebut. POJK yang dikeluarkan sebenarnya ketentuannya tidak jauh berbeda dengan PBI yang mengatur tentang upaya penyelesaian kredit bermasalah, hanya dibedakan karena POJK yang dikeluarkan ini mengatur lebih jelas dan dikarenakan adanya kondisi tertentu yaitu pandemi Covid-19. Dapat disimpulkan, penerapan POJK dalam kondisi overmacht sudah tepat hanya saja jangka waktunya perlu diperpanjang karena pada nyatanya sudah melewati tanggal 31 Maret 2021, kondisi dunia belum terbebas dari penyebaran virus Covid-19. Namun, secara keseluruhan isi dan ketentuan POJK sesuai dengan hukum yang berlaku, dengan menekankan pada pihak perbankan untuk tetap menerapkan prinsip kehati-hatian dalam memberikan relaksasi sebagai upaya keringanan untuk pinjaman atau kredit nasabah debitur.

\footnotetext{
${ }^{21}$ Pasal 2 Ayat (2) POJK NO. 11/POJK.03/2020

22 Pasal 10 POJK No. 11/POJK.03/2020
} 


\section{DAFTAR PUSTAKA}

Aminah. (2020). Pengaruh Pandemi Covid 19 Pada Pelaksanaan Perjanjian. Jurnal Diponegoro Private Law Review. doi: https://ejournal2.undip.ac.id/index.php/dplr/article/view/8172

Appludnopsanji, A., \& Disemadi, H. S. (2020). Problematika Kebijakan Pembebasan Narapidana sebagai Upaya Penanggulangan COVID-19 di Indonesia. Jurnal Wawasan Yuridika, 4(2), 131-148.

Ashshofa, Burhan. (1996). Metode Penelitian Hukum. Jakarta: PT. Rineka Cipta.

Charlina. (2020). 10 Alur Kredit Di Bank. Diambil 2 Juni 2021. Dari https://wartadana.com/10-alur-kredit-di-bank/

Disemadi, H. S., \& Handika, D. O. (2020). Community compliance with the covid-19 protocol hygiene policy in Klaten Regency, Indonesia. Legality: Jurnal Ilmiah Hukum, 28(2), 121-133.

Disemadi, H. S., \& Shaleh, A. I. (2020). Banking credit restructuring policy amid COVID-19 pandemic in Indonesia. Jurnal Inovasi Ekonomi, 5(02).

Fransisco, W. (2020). Interaktif Masyarakat Terhadap Hukum Dalam Kehidupan Normal Baru Pasca COVID-19. Journal of Judicial Review, 22(2), 151-164.

Fuady, Munir. (2007). Dinamika Teori Hukum. Bogor: Ghalia Indonesia.

Hetharie, Yosia. (2019). Perjanjian Nominee Sebagai Sarana Penguasaan Hak Milik Atas Tanah Oleh Warga Negara Asing Menurut KUHPerdata. Jurnal SASI. doi: https://doi.org/10.47268/sasi.v25i1.147

Ibrahim, Johnny. (2006). Teori dan Metodologi Penelitian Hukum Normatif. Malang: PT. Bayumedia Publishing.

Kamus Besar Bahasa Indonesia daring. Diambil 1 Juni 2021. Dari https://kbbi.kemdikbud.go.id/

Kang, C., \& Disemadi, H. S. (2021, March). The COVID-19 Pandemic Outbreak Impact And Prevention From Legal Perspective: An Indonesian Experience. In CoMBInESConference on Management, Business, Innovation, Education and Social Sciences Vol. 1, No. 1, 134-144.

Pengertian, Bentuk, Penyebab, dan Hukum Wanprestasi. Diambil 1 Juni 2021. Dari http://www.dppferari.org/pengertian-bentuk-penyebab-dan-hukumwanprestasi/

Rezki \& Yunus, N. (2020). Kebijakan Pemberlakuan Lockdown Sebagai Antisipasi Penyebaran Corona Virus Covid-19. Jurnal Sosial dan Budaya Syar-i. doi: https://doi.org/10.15408/sjsbs.v7i3.15083

Rothan, Hussin A. \& Byrareddy, Siddappa N. (2020). The epidemiology and pathogenesis of coronavirus disease (COVID-19) outbreak. Journal of Autoimmunity. doi: https://doi.org/10.1016/j.jaut.2020.102433

Sumaryanto, A Djoko \& Kunarso. (2020). Eksistensi Perjanjian Ditengah Pandemi Covid19. Jurnal Batulis Civil Law Review. doi: https://doi.org/10.47268/ballrev.v1i1.423

Syaifudin, A., \& Ernawati, E. (2020). Indonesia Investment Rules: Kajian Hukum Pemulihan Dan Pengembangan Ekonomi Nasional Dimasa COVID-19. Journal of Judicial Review, 22(2), 195-214.

Taniady, V., Riwayanti, N. W., Anggraeni, R. P., Ananda, A. A. S., \& Disemadi, H. S. (2020). PHK Dan Pandemi Covid-19: Suatu Tinjauan Hukum Berdasarkan Undang-Undang Tentang Ketenagakerjaan Di Indonesia. Jurnal Yustisiabel, 4(2), 97-117.

Taun, T. \& Nugraha, A. (2020). Penerapan Hukum dalam Pemutusan Hubungan Kerja dan Kebijakan Bank Terhadap Debitur yang Terdampak Pandemi Covid-19. Jurnal Batulis Civil Law Review. doi: https://doi.org/10.47268/ballrev.v1i1.422

Tjoanda, Merry \& Yosia Hetharie. (2021). Covid-19 Sebagai Bentuk Overmacht Dan Akibat Hukumnya. Jurnal SASI. doi: https://doi.org/10.47268/sasi.v27i1.447 
Yusmita. (2019). Perlindungan Hukum Terhadap Debitur dan Kreditur Dalam Melakukan Perjanjian Baku. Surabaya: DIH Jurnal llmu Hukum.

Peraturan Bank Indonesia No. 14/15/PBI/2012

POJK No. 11/POJK.03/2020 tentang Stimulus Perekonomian Nasional.

UU No. 10 Tahun 1998 tentang Perbankan

UU No. 12 Tahun 2011 tentang Pembentukan Peraturan Perundang-Undangan.

UU No. 24 Tahun 2007 tentang Penanggulangan Bencana. 